\title{
Intervention
}

\section{The outcome of bifurcation lesion stenting using a biolimus- eluting stent with a bio-degradable polymer compared to a sirolimus-eluting stent with a durable polymer}

Scot Garg', MB, ChB, MRCP; Joanna Wykrzykowska', MD; Patrick W. Serruys ${ }^{1 *}$, MD, PhD; Ton de Vries $^{2}$, MSc; Pawel Buszman ${ }^{3}, M D$, PhD; Stanislaw Trznade ${ }^{3}$, MD; Axel Linke ${ }^{4}$, MD, PhD; Karsten Lenk $^{4}, \mathrm{MD}$; Thomas Ischinger ${ }^{5}, \mathrm{MD}, \mathrm{PhD}$; Volker Klauss ${ }^{6}, \mathrm{MD}$, PhD; Franz Eberli? ${ }^{7}, \mathrm{MD}$; Roberto Corti ${ }^{8}$, MD; William Wijns ${ }^{9}$, MD, PhD; Marie-Claude Morice ${ }^{10}$, MD; Carlo di Mario ${ }^{11}$, MD, PhD; Pawel Tyczynski ${ }^{11}$, MD; Robert Jan van Geuns ${ }^{1}, \mathrm{MD}$, PhD; Pedro Eerdmans ${ }^{12}$, MD, PhD; Gerrit-Anne van Es ${ }^{2}$, PhD; Bernhard Meier ${ }^{13}$, MD; Peter Jïni ${ }^{14,15}$, MD; Stephan Windecker ${ }^{13,14}$, MD

1. Department of Interventional Cardiology, Erasmus MC, Rotterdam, The Netherlands; 2. Cardialysis B.V, Rotterdam, The Netherlands; 3. Medical University of Silesia, Katowice, Poland; 4. Herzzentrum Leipzig, Leipzig, Germany; 5. Department of Cardiology, Hospital Bogenhausen, Murich, Germany; 6. Department of Cardiology, University Hospital Munich (Innenstadt), Munich, Germany; 7. Currently working at department of Cardiology, Triemli Spital, Zurich, Switzerland; 8. Department of Cardiology, University Hospital Zurich, Zurich, Switzerland; 9. Department of Cardiology, Onze Lieve Vrouw Ziekenhuis, Aalst, Belgium; 10. Institut Jacques Cartier Massy, France; 11. Department of Cardiology, Royal Brompton Hospital, London, United Kingdom; 12. Biosensors Europe SA, Morges, Switzerland; 13. Department of Cardiology, Bern University Hospital, Bern, Switzerland; 14. CTU Bern, Bern University Hospital, Bern, Switzerland; 15. Institute of Social and Preventive Medicine, University of Bern, Bern, Switzerland

Windecker is a consultant for and receives fees from Abbolt Vascular, Boston Scientific. Cordis, Medtronic and Biosensors. Ebcrli is a speaker for Biosensors, and consultant for Cordis. Eerdmans is an employoc of Biosensors Europe. The remaining authors declare they have no conflict of intcrest to declare. Funding source. The LEADERS trial was funded by Biosensors, Europe SA, Switzerland.

\section{KEYWORDS}

Biolimus-eluting stent, sirolimus-eluting stent, bifurcation lesions, biodegradable polymer

\begin{abstract}
Aims: This study investigated the differences in clinical outcomes between patients with bifurcation lesions (BL) treated with a biolimus-eluting stent (BES) with a biodegradable polymer, and a sirolimus-eluting stent (SES) with a durable polymer.

Methods and results: The clinical outcomes were assessed in the 497 patients (BES 258, SES 239) enrolled in the multicentre, randomised LEADERS trial who underwent treatment of $\geq 1 \mathrm{BL}$ (total $=534 \mathrm{BL}$ ). At 12 . months follow-up there was no significant difference in the primary endpoint of MACE, a composite of cardiac death, myocardial infarction and clinically indicated target vessel revascularisation (BES $12.8 \%$ vs. SES $16.3 \%, p=0.31$ ). Patients treated with BES had comparable rates of cardiac death (BES $2.7 \%$ vs. SES $2.9 \%, p=1.00$ ), numerically higher rates of myocardial infarction (BES $8.9 \%$ vs. SES $5.4 \%, p=0.17$ ), and significantly lower rates of clinically indicated target vessel revascularisation $(4.3 \%$ vs. $11.3 \%, p=0.004)$ when compared to those treated with SES. The rate of stent thrombosis at 12 -months was $4.3 \%$ and $3.8 \%$ for BES and SES, respectively $(p=0.82)$.

Conclusions: In the treatment of BL the use of BES lead to superior efficacy and comparable safety compared to SES.
\end{abstract}

\footnotetext{
* Corresponding author: Ba583a, Thoraxcentre, Erasmus MC,'s-Gravendijkwal 230, 3015 CE Rotterdam, The Netherlands E-mail: p.w.j.c.serruys@erasmusmc.n!
} 


\begin{tabular}{|ll|}
\hline Abbreviations \\
ACS & Acute coronary syndrome \\
BES & Biolimus-eluting stent \\
BL & Bifurcation lesion \\
CABG & Coronary artery bypass graft surgery \\
DES & Drug-eluting stent \\
MACE & Major adverse cardiovascular events \\
MB & Main branch \\
MI & Myocardial infarction \\
MLD & Minimum luminal diameter \\
NSTEMI & Non-ST-elevation myocardial infarction \\
PCI & Percutaneous coronary intervention \\
RVD & Reference vessel diameter \\
SB & Side branch \\
SES & Sirolimus-eluting stent \\
ST & Stent thrombosis \\
TIMI & Thrombolysis in Myocardial Infarction \\
TLR & Target lesion revascularisation \\
TVR & Target vessel revascularisation \\
& \\
\hline
\end{tabular}

\section{Introduction}

Bifurcation lesions (BL) account for up to one third of coronary lesions and are associated with lower procedural success, and poorer clinical outcomes. ${ }^{1}$ The previously high rates of target lesion revascularisation (TLR) and major adverse cardiovascular events (MACE) observed after the treatment of $\mathrm{BL}$ with the use of bare metal sterits 1,2 have improved significantly following the introduction of drug eluting stents (DES), ${ }^{3,4}$ however safety concerns with respect to stent thrombosis (ST) have emerged. ${ }^{5}$ One of the potential causes of ST is delayed re-endothelialisation which may occur as a consequence of a hypersensitivity reaction induced by the presence of a permanent polymer. ${ }^{6.7}$ The concerns of ST have been greater with first generation DES with durable polymers, and recent studies have demonstrated numerically lower rates of ST with newer generation DES that have polymers which are more biocompatible, ${ }^{8,9}$ or completely biodegradable. ${ }^{10}$

The Biomatrix ${ }^{\top M}$ Flex biolimus eluting stent (BES) (Biosensors, Morges, Switzerland) elutes biolimus from a polylactic acid (PLA) biodegradable polymer applied to the stent's abluminal surface. The polymer is fully metabolised to water and carbon dioxide within 69 months, and therefore has the potential to cause less long-term inflammatory sequelae. In the randomised LEADERS (Limus Eluted from A Durable versus ERodable Stent coating) trial, BES was found to be non-inferior to the Cypher ${ }^{(m)}$ sirolimus eluting stent (SES) (Cordis, NJ, USA) in terms of MACE at nine months followup $(9 \%$ vs. $11 \%, p$ for non-inferiority=0.003, $p$ for superiority= 0.39).11

The objective of the present study was to investigate whether there were any differences in clinical outcomes between patients with $\mathrm{BL}$ treated with a DES with a biodegradable polymer (BES) compared to a DES with a durable polymer (SES).

\section{Method}

\section{Study population}

The methods of the LEADERS trial have been published previously." The study applied an all-comers approach recruiting 1,707 patients with chronic stable coronary artery disease or acute coronary syndromes (ACS) including ST-elevation myocardial infarction (STEMI), who were eligible for enrolment if they had at $\geq 1$ lesion with diameter stenosis (DS) $\geq 50 \%$ and a reference vessel diameter (RVD) $2.25-3.5 \mathrm{~mm}$. The principle exclusion criteria are described elsewhere. ${ }^{11}$ The study complied with the Declaration of Helsinki and was approved by all institutional ethics committees. All patients provided written, informed consent for participation in the trial.

In this analysis, patients with $\geq 1 \mathrm{BL}$ were identified using the electronic clinical record form (eCRF), and results from the core laboratory angiographic analysis which identified and classified all $\mathrm{BL}$ according to the SYNTAX bifurcation score. ${ }^{12}$ The angiograms of 497 patients (258 BES, 239 SES) who had a total of 534 BL (282 BES, 252 SES) identified using either source were reviewed by two investigators (SG and JW), who were blinded to outcomes and stent type. During review of the digital angiogram fitms, the presence of a BL was confirmed if a lesion of $\geq 50 \%$ DS on visual estimation was present in a main branch (MB) and/or a contiguous side branch $(\mathrm{SB})$ of $\geq 1.5 \mathrm{~mm}$ in diameter. Other information pertinent to the $\mathrm{BL}$ recorded during angiographic review was the number of guidewires used; stenting technique; use and site (MB, SB or both) of pre- and post-stenting dilatation; pre- and post-stenting TIMI flow and total number of stents used. Clinical outcomes were compared according to stent type, whilst procedural technique was compared between stents after dividing BL into "true" or "partial" BL. Those $B L$ with a Medina classification ${ }^{13}$ of $1,1,1 ; 1,0,1 ; 0,1,1$ (i.e., those with lesions involving both the MB and $\mathrm{SB}$ ) were defined as "true" $B L$, whilst those with a Medina classification of $1,0,0 ; 0,1,0 ; 1,1,0$; $0,0,1$ (i.e., those where either the $M B$ or $S B$ was involved) were defined as "partial" BL.

\section{Randomisation and procedures}

Patients were randomly allocated on a $1: 1$ basis to treatment with either a BES or SES, and to active angiographic follow-up at nine months or clinical follow-up only on a $1: 3$ basis with a factorial design. Percutaneous coronary intervention (PCl) was performed according to standard technique, and direct stenting was allowed. The choice of bifurcation stenting strategy and use of post stenting dilatation was left to the operator's discretion. No mixture of DES was permitted within a given patient, unless the operator was unable to insert the study stent, in which case crossover to another device of the operator's choice was possible. Procedural anticoagulation was achieved with unfractionated heparin 5000 IU or $70-100 \mathrm{lU} / \mathrm{kg}$, whilst the use of glycoprotein $\mathrm{Ilb} / \mathrm{llla}$ inhibitors was left to the operator's discretion. Pre-procedure all patients enrolled into the study received $\geq 75 \mathrm{mg}$ of acetylsalicylic acid, and $\geq 300 \mathrm{mg}$ of clopidogrel. All patients were discharged on $\geq 75 \mathrm{mg}$ of acetylsalicylic acid indefinitely, and clopidogrel $75 \mathrm{mg}$ for $\geq 12$ months following the index procedure. 


\section{Follow-up}

Adverse events were assessed in-hospital, and clinical follow-up was performed at $1,6,9$, and 12 months. One in four patients was asked to return for angiographic follow-up at nine months.

\section{Study endpoints}

The primary endpoint of this sub-study was MACE, defined as the composite of cardiac death, myocardial infarction (MI), and clinically-indicated target vessel revascularisation (TVR) within 12months. Secondary endpoints were death from any cause, cardiac death, MI, any TLR (both clinically and non-clinically indicated); any TVR, and $S T$.

A blinded independent clinical events committee adjudicated all endpoints, and independent study monitors verified all case reports from data on-site. The operators were by necessity aware of the assigned study stent during $\mathrm{PCl}$ and angiographic follow-up, but patients and staff involved in follow-up assessment were blinded to the allocated stent type. Angiography films were centrally assessed at one angiographic core laboratory (Cardialysis, Rotterdam, The Netherlands) with assessors unaware of the allocated stent.

\section{Definitions}

Definitions of all endpoints are provided in full elsewhere. ${ }^{.1} \mathrm{MI}$ was defined using the electrocardiographic criteria of the Minnesota code, or by a measured level of creatinine kinase (CK) two times the upper limit of normal (ULN), with either a positive concentration of CK-myoglobin fraction, or troponin 1 or $T$. Periprocedural MI was defined as any $\mathrm{MI} \leq 48$ hours of the index procedure. Revascularisation was regarded as clinically indicated if on quantitative coronary angiography (QCA) the lumen DS of the treated lesion was $\geq 50 \%$ in the presence of ischaemic signs or symptoms, or $\geq 70 \%$ in the absence of ischaemia. TVR was defined as any repeat $\mathrm{PCl}$ or surgical bypass of any segment within the entire major coronary vessel proximal and distal to a target lesion, including upstream and downstream branches and the target lesion itself. TLR was defined as a repeat revascularisation due to a stenosis within the stent or within a $5 \mathrm{~mm}$ border proximal or distal to the stent. ST was defined according to the Academic Research Consortium definitions. ${ }^{14}$

\section{Statistical analysis}

Continuous variables are expressed as meantstandard deviation; categorical data is presented as frequency (percentages). Patient demographic data was compared using the Student $t$-test, whilst $\chi^{2}$ was used for categorical data. Angiographic outcomes were analysed using SAS v8 Proc Mixed for continuous, and Proc Genmod for binominal outcomes, taking into account the withinpatient correlation structure of these data. Survival curves were constructed for time-to-event variables using Kaplan-Meier estimates, and compared by the log-rank test. The piecewise Cox proportional hazards model was used to compare clinical outcomes between the groups. All analyses were performed using SAS 8.02 by a dedicated statistician. All p-values and confidence intervals were two-sided; $p<0.05$ was considered statistically significant.

\section{Results}

\section{Baseline characteristics (Tables 1 and 2)}

A total of 1,707 patients were enrolled in the LEADERS study o which $29.1 \%$ (497 patients, $534 \mathrm{BL}$ ) had $\geq 1$ treated BL (Figure 1) The baseline clinical and lesion characteristics were well matched between those patients with BL treated with BES (258 patients) and SES (239 patients) as indicated in Tables 1 and 2.

\section{Procedural technique (Table 3 )}

The procedural technique employed to treat the $534 \mathrm{BL}$ is summarised in Table 3. There were no significant differences in technique when comparing BES to SES for picients with a true of a partial BL. Differences in technique did exist however when comparing true $\mathrm{BL}$ to partial $\mathrm{BL}$; those patients with a true bifurcation were significantly more likely to be treated with a two. stent strategy $(27.5 \%$ vs. $12.3 \%, p<0.0001)$ and receive post. stenting dilatation ( $52.4 \%$ vs. $36.5 \%, p=0.0003$ ).

\section{Clinical endpoints (Table 4)}

The hierarchical and non-hierarchical clinical outcomes at 1-year follow-up are shown in Table 4, and the Kaplan Meier survival curves are shown in Figure 2. There was no significant difference in

Table 1. Patient demographics and clinical presentation amongst patients with $\geq 1$ treated bifurcation lesion.

\begin{tabular}{|c|c|c|c|}
\hline $\begin{array}{l}\text { Variables, } n(\%) \\
\text { unless stated }\end{array}$ & $\begin{array}{c}\text { BES } \\
N=258 \\
\end{array}$ & $\begin{array}{c}\text { SES } \\
\mathrm{N}=239 \\
\end{array}$ & $p$ value \\
\hline \multicolumn{4}{|l|}{ Patient demographics } \\
\hline Age, years & $65.1 \pm 10.3$ & $64.2 \pm 10.9$ & 0.36 \\
\hline Male & $183(70.9)$ & $178(74.5)$ & 0.38 \\
\hline Body mass index, $\mathrm{kg} / \mathrm{m}^{2}$ & $27.2 \pm 4.0$ & $27.3 \pm 4.2$ & 0.63 \\
\hline Diabetes mellitus & $64(24.8)$ & $44(18.4)$ & 0.08 \\
\hline Hypertension & $187(72.5)$ & $175(73,2)$ & 0.85 \\
\hline Hypercholesterolaemia & $170(65.9)$ & $168(70.3)$ & 0.29 \\
\hline Current smoker & $45(17.4)$ & $57(23.8)$ & 0.08 \\
\hline Family history of CAD & $98(38.0)$ & $102(42.7)$ & 0.29 \\
\hline Previous MI & $92(35.7)$ & $93(38.9)$ & 0.45 \\
\hline Previous PCI & $98(38.0)$ & $93(38.9)$ & 0.83 \\
\hline Previous CABG & $19(7.4)$ & $28(11.7)$ & 0.10 \\
\hline Previous stroke & $17(6.6)$ & $8(3.3)$ & 0.10 \\
\hline Peripheral vascular disease & $17(6.6)$ & $17(7.1)$ & 0.82 \\
\hline Multivessel disease & $98(38.0)$ & $81(33.9)$ & 0.34 \\
\hline $\operatorname{LVEF}(\%)$ & $55.7 \pm 11.2$ & $53.8 \pm 12.9$ & 0.20 \\
\hline \multicolumn{4}{|l|}{ Clinical presentation } \\
\hline ACS & $135(52.3)$ & $133(55.6)$ & 0.46 \\
\hline STEMI & $29(11.2)$ & $32(13.4)$ & 0.47 \\
\hline NSTEMI & $36(14.0)$ & $49(20.5)$ & 0.053 \\
\hline Unstable angina & $70(27.1)$ & $52(21.8)$ & 0.16 \\
\hline Stable angina & $85(32.9)$ & $89(37.2)$ & 0.32 \\
\hline Silent ischaemia & $38(14.7)$ & $17(7.1)$ & 0.007 \\
\hline
\end{tabular}

AAll p-values: Chi-square test; ACS: acute coronary syndrome; BES; biolimuseluting stent; CABG: coronary artery bypass graft surgery; CAD: coronary artery disease; MI: myocardial infarctionv NSTEMI: non-ST elevation MI; PCI percutaneous coronary intervention; SES: sirolimus-eluting stents 
LEADERS population

2,467 lesions in 1,707 patients

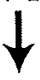

Randomised
Biolimus eluting stent

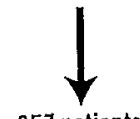

857 patients

- No bifurcation

- Bifurcation

1,254 lesions

- No bifurcation lesion
- Bifurcation lesions

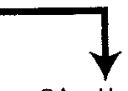

Sirolimus eluting stent

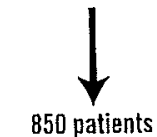

$$
\begin{aligned}
& 599 \\
& 258
\end{aligned}
$$$$
- \text { No bifurcation }
$$$$
\text { - Bifurcation }
$$

1,213 lesions

$972-$ No bifurcation lesion

$282-$ Bifurcation lesions
611

239

961

252
Figure 1. Flow chart indicating the number and type of bifurcation lesions, categorised according to make of stent.

the primary endpoint of MACE between BES and SES at 12-month follow-up (BES $12.8 \%$ vs. SES $16.3 \%, p=0.31$ ). The rate of death was comparable between stents, whilst the rate of clinicallyindicated TVR was significantly lower in those treated with BES ( $11.3 \%$ vs. $4.3 \%, p=0.004)$. Ml occurred more frequently in those treated with BES $(8.5 \%$ vs. $4.6 \%, p=0.10)$, and this was driven by the significantly higher incidence of periprocedural MI (MI 0-2 days: HR 2.53, 95\% Cl 1.1-6.0, $p=0.03$; MI 3-360 days: HR 0.64, 95\% Cl: $0.18-2.27, p=0.49$, Figure $2 B$ ).

\begin{tabular}{|c|c|c|c|c|c|}
\hline \multirow[b]{2}{*}{ Variables, $n(\%)$} & \multicolumn{2}{|c|}{ True bifurcations } & \multicolumn{2}{|c|}{ Partial bifurcation } & \multirow{2}{*}{$\begin{array}{c}\text { P value } \\
\text { True vs. } \\
\text { Partial } \\
\end{array}$} \\
\hline & $\begin{array}{c}\text { BES } \\
(n=131)\end{array}$ & $\begin{array}{c}\text { SES } \\
(n=102)\end{array}$ & $\begin{array}{c}\text { BES } \\
(n=151)\end{array}$ & $\begin{array}{c}\text { SES } \\
(n=150)\end{array}$ & \\
\hline Number of wires & & & & & 0.76 \\
\hline One & $32(24.4)$ & $27(26.5)$ & $30(19.8)$ & $42(28.0)$ & \\
\hline Two & $99(75.6)$ & $75(73.5)$ & $121(80.2)$ & $108(72.0)$ & \\
\hline Stenting technique & & & & & $\mathrm{p}<0.0001$ \\
\hline One stent & $94(71.8)$ & $75(73.5)$ & $129(85.4)$ & $135(90.0)$ & \\
\hline 1 wire & $32(24.4)$ & $27(26.5)$ & $30(19.9)$ & $42(28.0)$ & \\
\hline 2 wires (Provisional T-stent) & $55(42.0)$ & $41(40.2)$ & $57(37.7)$ & $59(39.3)$ & \\
\hline 2 wires (2nd wire post MB stenting) & $7(5.3)$ & $7(6.9)$ & $42(27.8)$ & $34(22.7)$ & \\
\hline Two stents & $37(28.2)$ & $27(26.5)$ & $22(14.6)$ & $15(10.0)$ & \\
\hline Cross-over from 1-stent technique & $7(5.3)$ & $8(7.8)$ & $6(4.0)$ & $3(2.0)$ & \\
\hline Classic $T$ & $7(5.3)$ & $8(7.8)$ & $9(6.0)$ & $7(4.7)$ & \\
\hline Crush & $16(12.2)$ & $7(6.9)$ & $3(2.0)$ & $4(2.7)$ & \\
\hline Culotte & $7(5.3)$ & $0(0.0)$ & $1(0.7)$ & $0(0.0)$ & \\
\hline Modified T & $0(0.0)$ & $1(1.0)$ & $2(1.3)$ & $0(0.0)$ & \\
\hline$V$ stenting & $0(0.0)$ & $3(2.9)$ & $1(0.7)$ & $1(0.7)$ & \\
\hline Post dilatation & $73(55.7)$ & $49(48.0)$ & $58(38.4)$ & $52(34.7)$ & $p=0.003$ \\
\hline MB only & $5(3.8)$ & $3(2.9)$ & $8(5.3)$ & $14(9.3)$ & \\
\hline MB-SB ostium & $16(12.2)$ & $14(13.7)$ & $19(12.6)$ & $16(10.7)$ & \\
\hline Kissing balloon & $52(39.7)$ & $32(31.4)$ & $31(20.5)$ & $22(14.7)$ & \\
\hline
\end{tabular}

Table 3. Summary of stenting technique.

\begin{tabular}{|c|c|c|c|}
\hline $\begin{array}{l}\text { Variables, } n(\%) \\
\text { unless stated }\end{array}$ & $\begin{array}{c}\text { BES } \\
\text { ( } n=282 \text { lesions) } \\
\end{array}$ & $\begin{array}{c}\text { SES } \\
\text { ( } n=252 \text { lesions) }\end{array}$ & $P$ value \\
\hline \multicolumn{4}{|l|}{ Angiographic characteristics } \\
\hline \multicolumn{4}{|l|}{ Vessels with } \\
\hline a lesion $>50 \%$ & $1.25 \pm 0.55$ & $1.19 \pm 0.61$ & 0.22 \\
\hline Lesions $>50 \%$ & $1.43 \pm 0.70$ & $1.40 \pm 0.79$ & 0.64 \\
\hline \multicolumn{4}{|c|}{ Vessel territory (per lesion) } \\
\hline LAD 22 & $222 / 452(49.1)$ & $208 / 417(49.9)$ & 0.82 \\
\hline $\mathrm{RCA}$ & $74 / 452(16.4)$ & $75 / 417(18.0)$ & 0.68 \\
\hline $\mathrm{LCx}$ & $138 / 452(30.5)$ & $123 / 417(29.5)$ & 0.78 \\
\hline Left main stem & $18 / 452(4.0)$ & $8 / 417(1.9)$ & 0.08 \\
\hline CABG & $0 / 452(0.0)$ & $3 / 417(0.7)$ & n.d.* \\
\hline SYNTAX score ${ }^{9}$ & $16.8 \pm 8.4$ & $16.7 \pm 8.9$ & 0.93 \\
\hline & $(n=198)$ & $(n=182)$ & \\
\hline \multicolumn{4}{|l|}{ Postprocedure } \\
\hline Number of stents & $2.4 \pm 1.5$ & $2.2 \pm 1.3$ & 0.33 \\
\hline Number of stented lesions & $1.75 \pm 0.80$ & $1.74 \pm 0.77$ & 0.92 \\
\hline Mean stent diameter, mm & $2.88 \pm 0.33$ & $2.89 \pm 0.32$ & 0.89 \\
\hline Mean stent length, mm & $17.6 \pm 14.7$ & $17.8 \pm 4.9$ & 0.72 \\
\hline Total stent length, mm & $40.9 \pm 25.8$ & $39.8 \pm 26.1$ & 0.64 \\
\hline Use of glycoprotein $2 b / 3 a$ & $65(25.2)$ & $46(19.2)$ & 0.11 \\
\hline Hospital stay, days & $3.2 \pm 3.1$ & $3.2 \pm 3.1$ & 0.88 \\
\hline
\end{tabular}

Table 2. Baseline lesions and procedural characteristics.

*At least one observation required in both groups; ${ }^{\mathrm{p}}$ only calculated if both left and right angiograms were available; patients with previous CABG excluded; CABG, SES and BES as before; LVEF: leit ventricular ejection $L C x$ : left circumflex artery fraction; $L A D$ : left anterior descending artery; RCA: right coronary artery;

BES: biolimus-eluting stent; SES: sirolimus-eluting stent; MB: main branch; SB: side branch; No significant difference in technique between BES and SES for true or partial bifurcation 

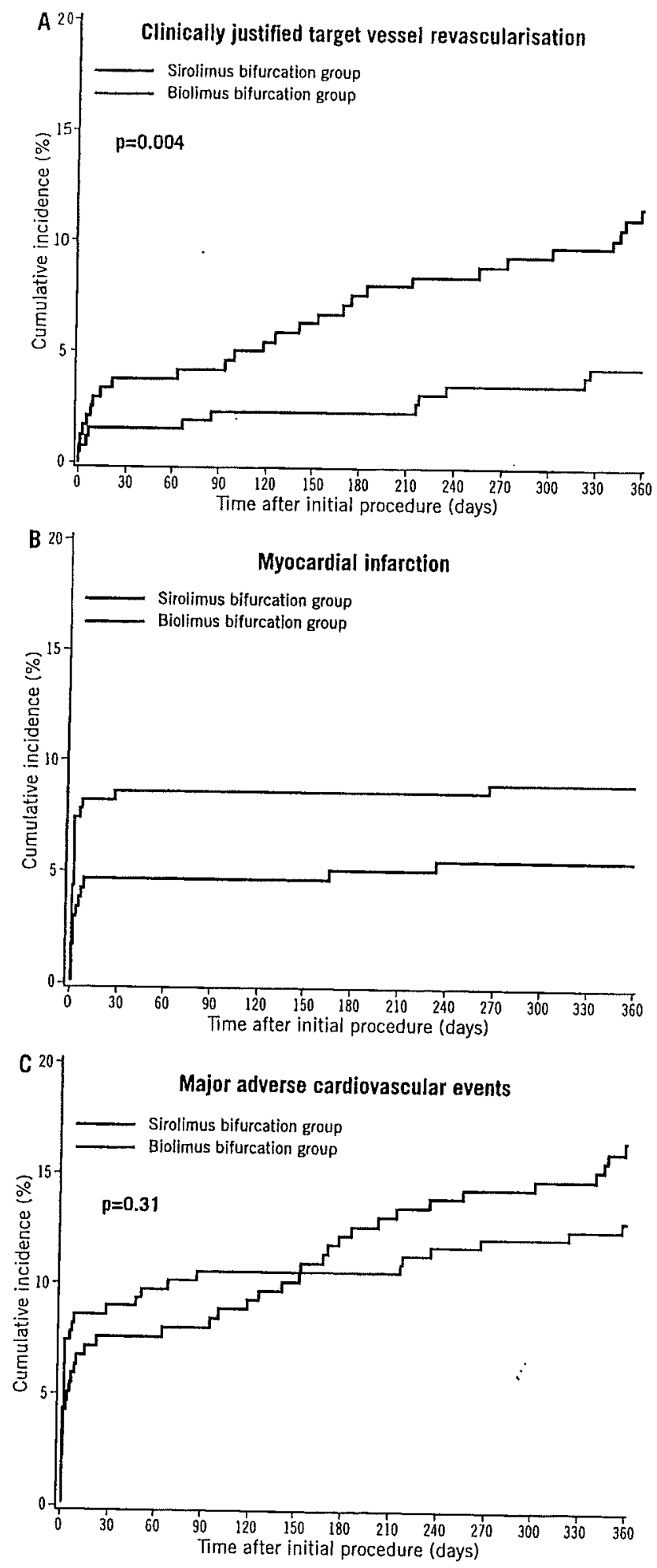

Figure 2. Kaplan Meier survival curves for (A) clinically indicated target vessel revascularisation, $(B)$ myocardial infarction, and (C) MACE.

The primary endpoint at 12 -months was not influenced by the type of $B L$ treated (true or partial), or the stenting technique used (one or two-stent strategy); however compared to SES, the use of BES was associated with significantly lower rates of percutaneous revascularisation (TLR and TVR) amongst those patients with a true $B L$, and those treated with one-stent $(p<0.05$ for all).
Table 4. Clinical outcomes at 1-year follow-up.

\begin{tabular}{lrrr} 
Outcome n(\%) & $\begin{array}{c}\text { BES } \\
(n=258)\end{array}$ & $\begin{array}{c}\text { SES } \\
(n=239)\end{array}$ & P Value \\
\hline Hierarchical outcomes (1-year) & & & \\
$\quad$ Cardiac death & $7(2.7)$ & $7(2.9)$ & 1.00 \\
MI & $21(8.1)$ & $12(5.0)$ & \\
Q-wave & $3(1.2)$ & $2(0.8)$ & \\
$\quad$ Non-Q wave & $18(7.0)$ & $10(4.2)$ & \\
Clinically justified TVR & $5(1.9)$ & $20(8.4)$ & \\
$\quad$ Percutaneous & $4(1.6)$ & $18(7.5)$ & \\
$\quad$ Surgical & $1(0.4)$ & $2(0.8)$ & \\
Any MACE & $33(12.8)$ & $39(16.3)$ & 0.31
\end{tabular}

Non-hierarchical outcomes (1-year)

Death

Cardiac death

MI

All TLR

Percutaneous

Surgical

Clinically justified TLR

Percutaneous

Surgical

All TVR

Percutaneous

Surgical

$9(3.5)$

$7(2.9)$

nically justified TVR

Percutaneous

Surgical

$7(2.7)$

$7(2.9)$

0.80

23(8.9)

$13(5.4)$

1.00

$12(4.7) \quad 29(12.1) \quad 0.003$

$12(4.7) \quad 28(11.7) \quad 0.005$

$\begin{array}{lll}1(0.4) & 4(1.7) & 0.20\end{array}$

$9(3.5) \quad 23(9.6) \quad 0.006$

$9(3.5) \quad 22(9.2) \quad 0.009$

$1(0.4) \quad 2(0.8) \quad 0.61$

$16(6.2) \quad 34(14.2) \quad 0.004$

$14(5.4) \quad 32(13.4) \quad 0.003$

$3(1.2) \quad 5(2.1) \quad 0.49$

11(4.3) $27(11.3) \quad 0.004$

$11(4.3) \quad 26(10.9) \quad 0.006$

$1(0.4) \quad 3(1.3) \quad 0.36$

TLR: target lesion revascularisation; TVR: target vessel revascularisation; MACE: major adverse cardiovascular events; MI, BES, SES as previously described

\section{Stent thrombosis (Table 5)}

The overall rates of early and late ST were similar between all patients treated with BES or SES, which was irrespective of the type of BL treated (True BL: BES 5.6\% vs. SES $4.0 \%, p=0.76$; Partial $B L$ : BES $3.0 \%$ vs. SES $3.6 \%, p=1.00$ ); or the number of stents used (one stent strategy: BES $4.9 \%$ vs. SES $3.6 \%, p=0.62$; two stent strategy: BES $1.9 \%$ vs. SES $4.8 \%, p=0.48)$.

Table 5. Stent thrombosis events at 30-days and 1-year.

\begin{tabular}{lrrr} 
& $\begin{array}{c}\text { BES } \\
(\mathbf{n = 2 5 8})\end{array}$ & $\begin{array}{c}\text { SES } \\
(\mathbf{n = 2 3 9 )}\end{array}$ & $p$ value \\
\hline 30-days & & & \\
$\quad$ Stent thrombosis & $7(2.7)$ & $7(2.9)$ & 1.00 \\
$\quad$ Definite & $5(1.9)$ & $6(2.5)$ & 0.76 \\
$\quad$ Possible & $0(0.0)$ & $0(0.0)$ & n.d. \\
$\quad$ Probable & $2(0.8)$ & $1(0.4)$ & 1.00 \\
1-year & & & \\
$\quad$ Stent thrombosis & $11(4.3)$ & $9(3.8)$ & 0.82 \\
$\quad$ Definite & $5(1.9)$ & $6(2.5)$ & 0.77 \\
$\quad$ Possible & $4(1.5)$ & $2(0.8)$ & 0.69 \\
$\quad$ Probable & $2(0.8)$ & $1(0.4)$ & 1.00 \\
\hline
\end{tabular}

$B E S, S E S$ as previously described; $n . d^{*}$; not done ( $\geq 1$ observation required in both groups) 


\section{liscussion}

his is the first analysis comparing the management of patients with .L using a DES with a biodegradable polymer to a DES with a urable polymer, and demonstrates similar overall clinical outcomes etween both patient groups, irrespective of the type of BL treated $r$ the stenting strategy used.

\section{'linical outcomes}

he use of DES have improved outcomes in patients with complex oronary artery disease, with significant reductions in restenosis, owever "off-label" use of DES, such as in BL, is still associated with igher rates of restenosis and ST compared to "on-label" use. ${ }^{15,16}$ ncouraging evidence from this study suggests newer DES, such as IES, may have the potential to improve some of these adverse linical outcomes. In this study the significantly lower rate of repeat svascularisation in those patients treated with BES was achieved espite any significant differences between stent groups in baseline linical, angiographic and lesion characteristics, or in procedural schnique. This suggests other factors such as differences in stent esign, strut thickness, cell size and the drug polymer may have lad an influential role on restenosis, as indicated by previous tudies comparing different $D E S$ in patients with $B L$ treated with the ame stenting technique. For example Pan et al reported significantly lower rate of TLR with Cypher (Cordis, Johnson \& ohnson, Warren, NJ, USA) compared to the TAXUS (Boston icientific, Natick, MA, USA) stent ( $4 \%$ vs. $13 \%, \mathrm{p}<0.05$ ) in 205 ratients undergoing provisional $T$ stenting, ${ }_{1}^{17}$ wiilst more recently, in ratients undergoing culotte stenting, Adriaenssens et al reported estenosis rates of $18 \%, 29 \%$ and $35 \%$ with Cypher, Endeavor Medtronic, Minneapolis, MN, USA) and TAXUS stents, respectively $p=0.12) .{ }^{18}$ These repeated observations warrant formal assessment 1 dedicated randomised trials.

7 contrast to this reduction in repeat revascularisation, those ratients treated with BES had a numerically higher incidence of MI, vhich was irrespective of the type of $\mathrm{BL}$ treated or the stenting trategy employed. Additional analysis indicates that these events vere driven by a significantly higher rate of periprocedural Mi with $3 \mathrm{ES}$, which in the vast majority was triggered by the detection of a ise in cardiac enzymes.

It though these periprocedural Mls are a concern, their overall ignificance is questionable when considering that the rate of death Imongst patients who sustained an $\mathrm{Ml}$ was $0.0 \%$ at 30 -days. towever, setting this, and the on-going discussion regarding the ignificance of periprocedural Mis aside for a moment, ${ }^{19}$ there is no lisputing that these events did occur, and with a greater frequency 7 those patients treated with BES. Enzyme rises may be secondary o procedural factor ${ }^{20}$ however in this study amongst those patients :xperiencing a periprocedural $\mathrm{MI}$ there were no significant lifferences between stent groups in TIMI flow (MB or SB) either preir post-PCl, or plaque shift. Notably however lesion pre-dilatation vas significantly higher in the group of patients with periprocedural Als who were treated with BES ( $88 \%$ vs. $43 \%, p=0.03$ ).

he physical properties of the stent may also influence enzyme elease. For example a smaller cell size can increase the chances of side branch occlusion; however bench studies indicate that the maximum cell circumference of a $3 \mathrm{~mm}$ BES is $10.8 \mathrm{~mm}$ compared to $9.5 \mathrm{~mm}$ in a similarly sized SES. Another physical stent property which merits discussion is the integrity of the polymer coating. Basalus et al recently evaluated the biodegradable coating on BES in vitro using electron microscopy, and observed cracks in the polymer after high pressure balloon inflation, which could potentially lead to the formation of free polymer fragments, capable of embolising and causing subsequent enzyme release. ${ }^{21}$ These observations however must be interpreted with caution because these assessments were performed in vitro which may have affected the polymer's stability, and without the use of vascular phantoms which may have stabilised the polymer. In addition, the significant reductions in TLR and TVR with BES are unlikely to have been observed in the presence of polymer fragmentation which ultimately would have reduced the dose of biolimus that could be eluted.

\section{Stent thrombosis}

A DES with a biodegradable polymer offers the potential to reduce the risk of late/very-late $\mathrm{ST}$, which is pertinent in patients with $\mathrm{BL}$, as these lesions represent an independent risk factor for ST, and have higher rates of ST when compared with non-BL treated with the same DES ( $p=$ not significant). ${ }^{5,22}$ The cause of this increased risk of ST is likely to be multi-factorial, but stent malapposition, and incomplete stent expansion, particularly in angulated bifurcation lesions, are likely to be two major contributing factors. ${ }^{23}$ Reassuringly recent studies have dispelled the initial concerns that rates of ST are higher with the use of complex as opposed to simple stenting strategies, or between different complex strategies. ${ }^{24.28}$ Following on from this, the rates of ST in this study were similar irrespective of stent type (BES vs. SES), type of $B L$ (partial vs. true) or stenting strategy used (one vs, two). Encouragingly provisional results from 2-year follow-up of all patients enrolled in the LEADERS trial does suggest a reduction in very late ST events in patients treated with a stent with a biodegradable polymer ${ }^{29}$ however the current study is not powered in isolation to draw any definitive conclusions regarding ST.

\section{Stenting technique for bifurcation lesions}

Despite the frequent occurrence of $B L$, the optimal procedurai strategy remains to be established. In the current study a singlestent strategy was preferred for $\mathrm{BL}$, being used to treat over $80 \%$ of cases, with a respectable cross over rate from a one to a two stent strategy of $5.3 \%$, and comparable MACE rates of $14.0 \%$ and $16.7 \%$ for one and two stent strategies, respectively. Historically a two stent strategy was considered the ideal method of dealing with a $B L$ as this produced the best angiographic result, however data from multiple randomised studies ${ }^{3,24,30-33}$ and three recent metaanalyses indicate that a provisional stenting strategy is as efficacious as a two stent strategy. ${ }^{25,26,34}$ The current study supports this data, and demonstrates that these results are achievable in an unselected population where $\geq 50 \%$ of patients were treated for ACS. 


\section{Limitations}

This sub-group analysis is limited by its post-hoc nature. The initial study was not a dedicated bifurcation study, and therefore angiographic analysis of $\mathrm{BL}$ was only available using conventional QCA. It is widely recognised that this is limited in its ability to accurately assess a $\mathrm{BL}$, and as a consequence no QCA data is presented here..$^{35}$ In view of the results obtained a more detailed assessment of $\mathrm{BL}$ is warranted using dedicated bifurcation software; however the number of patients with $\mathrm{BL}$ returning for follow-up angiography is also a potential limiting factor of the analysis.

\section{Conclusion}

In the treatment of $B L s$, the use of BES lead to superior efficacy and comparable safety compared to SES.

\section{References}

1. Al Suwaidi J, Yeh W, Cohen HA, Detre KM, Williams DO, Holmes DR, $J$ r. Immediate and one-year outcome in patients with coronary bifurcation lesions in the modern era (NHLBI dynamic registry). Am J Cardiol. 2001;87:1139-1144.

2. Yamashita $T$, Nishida $T$, Adamian $M G$, Briguori $C$, Vaghetti $M$, Conaja $N$, Albiero R, Finci L, Di Mario $C$, Tobis JM, Colombo $A$. Bifurcation lesions: two stents versus one stent-immediate and follow-up results. J Am Coll Cardiol, 2000;35:1145-1151.

3. Colombo A, Moses JW, Morice MC, Ludwig J, Holmes DR, Jr., Spanos V, Louvard Y, Desmedt B, Di Mario C, Leon MB. Randomized study to evaluate sirolimus-eluting stents implanted at coronary bifurcation lesions. Circulation. 2004;109:1244-1249.

4. Tanabe K, Hoye A, Lemos PA, Aoki J, Arampatzis CA, Saia F, Lee CH, Degertekin $M$, Hofma SH, Sianos G, McFadden $E$, Smits $P C$, van der Giessen WJ, de Feyter P, van Domburg RT, Serruys PW. Restenosis rates following bifurcation stenting with sirolimus-eluting stents for de novo narrowings. Am J Cardiol. 2004;94:115-118.

5. van Werkum JW, Heestermans AA, Zomer AC, Kelder JC, Suttorp MJ, Rensing BJ, Koolen JJ, Brueren BR, Dambrink JH, Hautvast RW, Verheugt FW, ten Berg JM. Predictors of coronary stent thrombosis: the Dutch Stent Thrombosis Registry. J Am Coll Cardiol. 2009;53:1399-1409.

6. Joner M, Finn AV, Farb A, Mont EK, Kolodgie FD, Ladich E, Kutys R, Skorija K, Gold HK, Virmani R. Pathology of drug-eluting stents in humans: delayed healing and late thrombotic risk. J Am Coll Cardiol. 2006;48:193-202.

7. van der Giessen WJ, Lincoff AM, Schwartz RS, van Beusekom HM, Serruys PW, Holmes DR, Jr., Ellis SG, Topol EJ. Marked inflammatory sequelae to implantation of biodegradable and nonbiodegradable polymers in porcine coronary arteries. Circulation. 1996;94:1690-1697.

8. Garg S, Serruys PW, Onuma $Y$, Dorange $C$, Veldhof $S$, MiquelHebert K, Sudhir K, Boland J, Huber KC, Garcia E, Riele te JAM. Three year clinical follow up of the XIENCE $\vee$ Everolimus eluting coronary stent system in the treatment of patients with de novo coronary artery lesions. The SPIRIT II Trial. J Am Coll Cardiol Intv. 2009;2:1190-1198.

9. Hamm C. 5 years later and more than 20,000 patients studied: the ENDEAVOR clinical programme. EuroPCR 19th-22nd May 2009; Barcelona [online] Available: www.europcronline.com/fo/lecture/ view_slide.php?idCongres= 5\&id=7617 [Accessed 20th June 2009].

10. Chevalier B, Silber S, Park S-J, Garcia E, Schuler G, Suryapranata $H$, Koolen J, Hauptmann KE, Wijns W, Morice M-C, Carrie D, van Es G-A, Nagai H, Detiege D, Paunovic D, Serruys PW, for the NCl. Randomized
Comparison of the Nobori Biolimus A9-Eluting Coronary Stent With the Taxus Liberte Paclitaxel-Eluting Coronary Stent in Patients With Stenosisir Native Coronary Arteries: The NOBORI 1 Trial-Phase 2. Circ Cardiovas: Intervent. 2009;2:188-195.

11. Windecker $S$, Serruys PW, Wandel S, Buszman $P$, Trznadel S, LinkeA Lenk $K$, Ischinger $T$, Klauss V, Eberli F, Corti R, Wijns W, Morice MC, d Mario C, Davies S, van Geuns RJ, Eerdmans P, van Es GA, Meier B, JuniP. Biolimus-eluting stent with biodegradable polymer versus sirolimus-elu. ing stent with durable polymer for coronary revascularisation (LEADERS); a randomised non-inferiority trial. Lancet. 2008;372:1163-1173.

12. Sianos G, Morel MA, Kappetein AP, Morice MC, Colombo A, Dawkins $K$, van den Brand M, Van Dyck N, Russell ME, Serruys P. The SYNTAX score: an angiographic tool grading the complexity of coronan; artery disease. Eurolntervention. 2005;1:219-227.

13. Medina A, Suarez de Lezo J, Pan M. IA new classification of coronary bifurcation lesions]. Rev Esp Cardiol. 2006;59:183.

14. Cutlip DE, Windecker S, Mehran R, Boam A, Cohen DJ, van ES GA. Steg PG, Morel MA, Mauri L, Vranckx P, McFadden E, Lansky A, Hamon M. Krucoff MW, Serruys PW. Clinical end points in coronary stent trials: a case for standardized definitions. Circulation. 2007;115:2344-2351.

15. Kirtane AJ, Gupta A, lyengar S, Moses JW, Leon MB, Applegate R, Brodie B, Hannan E, Harjai K, Jensen LO, Park SJ, Perry R, Racz M, Saia F, Tu JV, Waksman R, Lansky AJ, Mehran R, Stone GW. Safety and efficacy o! drug-eluting and bare metal stents: comprehensive meta-analysis of randomized trials and observational studies. Circulation. 2009;119:3198-3206.

16. Lasala JM, Cox DA, Lewis SJ, Tadros PN, Haas RC, Schweiger MJ, Chhabra A, Untereker WJ, Starzyk RM, Mascioli SR, Dawkins KD, Baim DS. Expanded use of the TAXUS Express Stent: two-year safety insights from the 7,500 patient ARRIVE Registry programme. Eurolntervention. 2009;5:67-77.

17. Pan M, Suarez de Lezo J, Medina A, Romero M, Delgado A, Segura J, Ojeda S, Mazuelos F, Hernandez E, Melian F, Pavlovic D, Esteban $F_{1}$ Herrador J. Drug-eluting stents for the treatment of bifurcation lesions: a randomized comparison between paclitaxel and sirolimus stents. Am Heart J. 2007;153:15 el1-17.

18. Adriaenssens T, Byrne RA, Dibra A, lijima R, Mehilli J, Bruskina 0, Schomig $A$, Kastrati $A$. Culotte stenting technique in coronary bifurcation disease: angiographic follow-up using dedicated quantitative coronary angiographic analysis and 12-month clinical outcomes. Eur Heart J. 2008;29:2868-2876.

19. Vranckx P, Cutlip D, Mehran R, Kint P-P, Silber $S$, Windecker $S$, Serruys PW. Myocardial Infarction adjudication in Contemporary AllComer Stent trials: Balancing sensitivity and specificity. Eurolntervention. 2010;5:871-4.

20. Nageh T, Sherwood RA, Harris BM, Byrne JA, Thomas MR. Cardiac troponin $\mathrm{T}$ and $\mathrm{I}$ and creatine kinase-MB as markers of myocardial injury and predictors of outcome following percutaneous coronary intervention. Int J Cardiol. 2003;92:285-293.

21. Basalus $M W$, van Houwelingen $K G$, Ankone $M$, de $M a n F H$, von Birgelen C. Scanning electron microscopic assessment of the biodegradable coating on expanded biolimus-eluting stents. Eurolntervention. 2009;5:505-510.

22. Tsuchida K, Colombo A, Lefevre T, Oldroyd KG, Guetta V, Guagliumi G, von Scheidt W, Ruzyllo W, Hamm CW, Bressers M, Stoll HP, Wittebols $K_{\text {, }}$ Donohoe DJ, Serruys PW. The clinical outcome of percutaneous treatment of bifurcation lesions in multivessel coronary artery disease with the sirolimus-eluting stent: insights from the Arterial Revascularization Therapies Study part II (ARTS II). Eur Heart J. 2007;28:433-442. 
23. Garg S, Serruys P. A Review of the Benefits of and Safety Concerns ssociated with Drug Eluting Coronary Stents. Expert Rev Cardiovasc her. 2010;8:449-70.

24. Colombo A, Bramucci E, Sacca S, Violini R, Lettieri $C$, Zanini R, heiban I, Paloscia L, Grube E, Schofer J. Bolognese L, Orlandi M, Niccoli G, atib A, Airoldi F. Randomized Study of the Crush Technique Versus rovisional Side-Branch Stenting in True Coronary Bifurcations: The CACUS (Coronary Bifurcations: Application of the Crushing Technique Using irolimus-Eluting Stents) Study. Circulation. 2009;119:71-78.

25. Brar S, Gray W, Dangas G, Leon M, Aharonian V, Brar S, Moses J. ifurcation Stenting with Drug-Eluting Stents: A Meta-Analysis urolntervention. 2009:5:475-484.

26. Zhang $F$, Dong $L$, Ge J. Simple versus Complex Stenting Strategy for oronary Artery Bifurcation Lesions in the Drug-Eluting Stent Era: a Metanalysis of Randomized Trials. Heart. 2009;95:1676-81.

27. Erglis $A$, Kumsars I, Niemela $M$, Kervinen $K$, Maeng $M$, Lassen JF, unnes $P$, Stavnes $S$, Jensen JS, Galloe $A$, Narbute I, Sondore $D$, lakikallio T, Ylitalo $K$, Christiansen EH, Ravkilde J, Steigen TK, lannsverk $J$, Thayssen $P$, Hansen $K N$, Syvanne $M$, Helqvist $S$, Kjell $N$, liseth R, Aaroe J, Puhakka M. Thuesen L, for the Nordic PCISG. andomized Comparison of Coronary Bifurcation Stenting With the Crush ersus the Culotte Technique Using Sirolimus Eluting Stents: The Nordic tent Technique Study. Circ Cardiovasc Intervent. 2009;2:27-34.

28. Ferenc $M$, Gick $M$, Kienzle RP, Bestehorn HP, Werner KD, :omberg $T$, Kuebler P, Buttner HJ, Neumann FJ. Randomized trial on Jutine vs. provisional T-stenting in the treatment of de novo coronary ifurcation lesions. Eur Heart J. 2008;29:2859-2867.

29. Klauss V. LEADERS: Twa-Year Follow-up from a Prospective landomized Trial of Biolimus A9-Eluting Stents with a Bioabsorbable
Polymer vs. Sirolimus-Eluting Stents with a Durable Polymer. Presentation Transcatheter Cardiovascular Therapeutics, San Francisco, 22nd September 2009.

30. Latib A, Colombo A, Sangiorgi GM. Bifurcation stenting: current strategies and new devices. Heart. 2009:95:495-504.

31. Pan M, de Lezo JS, Medina A, Romero M, Segura J, Pavlovic D, Delgado A, Ojeda S, Melian F, Herrador J, Urena I, Burgos L. Raparnycineluting stents for the treatment of bifurcated coronary lesions: a randomized comparison of a simple versus complex strategy. Am Heart $J$. 2004;148:857-864.

32. Jensen JS, Galløe A, Lassen JF, Erglis A, Kumsars I, Steigen TK, Wiseth R, Narbute I, Gunnes P, Mannsverk J. Safety in simple versus complex stenting of coronary artery bifurcation lesions. The nordic bifurcation study 14-month follow-up results. Eurolntervention. $2008: 4: 229$

33. Hildick-Smith D, de Belder AJ, Cooter N, Curzen NP, Clayton TC, Oldroyd KG, Bennett L, Holmberg S, Cotton JM, Glennon PE, Thomas MR, Maccarthy PA, Baumbach A, Mulvihill NT, Henderson RA, Redwood SR, Starkey IR, Stables RH. Randomized trial of simple versus complex drugeluting stenting for bifurcation lesions: the British Bifurcation Coronary Study: old, new, and evolving strategies. Circulation 2010;121:1235-43.

34. Katritsis DG, Siontis GCM, loannidis JPA. Double Versus Single Stenting for Coronary Bifurcation Lesions: A Meta-Analysis. Circ Cardiovasc Intervent, 2009;2:409-415.

35. Lansky A, Tuinenburg J, Costa M, Maeng M, Koning G, Popma J, Cristea $E$, Gavit L, Costa R, Rares A, Van Es GA, Lefevre T, Reiber $H$, Louvard $Y$, Morice MC. Quantitative angiographic methods for bifurcation lesions: a consensus statement from the European Bifurcation Group. Catheter Cardiovasc Interv. 2009;73:258-266. 